\title{
KOMUNITAS IKAN KARANG DI PERAIRAN \\ PANTAI PULAU RAKITI DAN PULAU TAIKABO, TELUK SALEH, NUSA TENGGARA BARAT
}

\author{
Sri Turni Hartati") dan (sa Nagib Edrus "*)
}

\begin{abstract}
ABSTRAK
Karang di perairan Teluk Saleh mengalami kerusakan yang serius di hampir semua terumbu pada pulaupulau yang ada, termasuk Pulau Rakiti dan Taikabo. Program rehabilitasi perairan Teluk Saleh membutuhan data dasar. Salah satu peubah yang dibutuhkan untuk mengevaluasi dan memonitor perubahan lingkungan perairan adalah ikan karang, karena ikan karang dapat dipakai sebagai indikator yang sesuai untuk menunjukkan habitat karang yang mengalami gangguan. Penelitian ini bertujuan untuk mengidentifikasi jenisjenis ikan setempat yang ada dan menghitung beberapa indeks yaitu indeks keanekaragaman ikan $(H)$, indeks dominasi (D atau Simpson), indeks keseimbangan, dan kepadatan ikan $\left(\mathrm{m}^{2}\right)$. Metode yang digunakan dalam pengumpulan data adalah sensus visual pada garis transek. Hasil sensus menunjukkan bahwa jumlah keseluruhan ikan karang yang ditemukan di lokasi penelitian adalah 105 jenis yang bervariasi antara 34 sampai 57 jenis pada masing-masing tempat transek. Kepadatan ikan di antara tempat transek bervariasi, antara 3,4 sampai 17,7 ekor per meter persegi. Indeks keanekaragaman ikan tergolong rendah pada keseluruhan lokasi transek dan berkisar 2,54 sampai 3. Indeks dominasi pada masing-masing lokasi transek berkisar 0,08 sampai 0,14 , sedangkan indeks keseimbangan berkisar 0,72 sampai 0,75 . Hal ini, berarti bahwa tidak ada dominasi antara populasi dan tidak ada gangguan yang berarti dalam komunitas ikan karang.
\end{abstract}

ABSTRACT: The current status of coral fish community in the Coastal Water of Rakiti and Taikabo Islands, Saleh Bay, Nusa Tenggara Barat. By: Sri Turni Hartati and Isa Nagib Edrus

The reefs of Saleh Bay were in serious degradation occurring in across the islands, included Rakiti and Taikabo. The need of baseline data may upsurge in regarding of rehabilitation program for the this bay. One of variables needed to evaluate and monitor the changing coastal water environment is coral fish. Coral fish is a suitable indikator of unsettled coral habitats. Hence, this study identified the intrinsic species and some indeces including the fish diversity index $(H)$, dominance index ( $D$ or Simpson), evenness index $(E)$, and fish density $\left(\mathrm{m}^{2}\right)$. The method used in data gathering was a census visual transect. The results show that total coral fish kinds found in the study areas was 105 species, variying from 34 to 57 species for respective transect sites. Fish density varied as well, from 3.4 to 17.7 ind $\mathrm{m}^{-2}$. Fish diversity indeces $(H)$ were low level for the whole transect sites and ranged from 2.54 to 3. Dominance or Simpson indeces for the respective-transect sites ranged from 0.08 to 0.14 , whereas evenness indeces ranged from 0.72 to 0.75 . It means that there are no population dominance and significant dissilution in the coral fish community.

KEYWORD: coral fish, ecological indeces, Rakiti Island, Taikabo Island, Saleh Bay, Nusa Tenggara Barat

\section{PENDAHULUAN}

Indonesia sebagai negara kepulauan terbesar di dunia memiliki kurang lebih $85.700 \mathrm{~km}^{2}$ wilayah terumbu karang atau $14 \%$ dari luas terumbu karang di dunia (Nontji, 2002). Sejumlah besar dari area terumbu karang tersebut telah mengalami degradasi yang cukup parah. Penelitian P30 LIPI pada tahun 2000 menunjukkan bahwa $72 \%$ terumbu karang Indonesia tergolong rusak dan rusak berat, dan selebihnya hanya $28 \%$ yang tergolong dalam kondisi baik dan baik sekali (KPP-CORAMAP, 2001). Besarnya kerusakan ekosistem terumbu karang berdampak buruk terhadap kehidupan sosial, ekonomi, dan budaya dari orang-orang yang hidup secara harmonis dan bergantung pada ekosistem tersebut untuk kebutuhan rekreasi, pengamanan, material, dan pendapatan (Wilkinson \& Buddemeier, 1994).
Peningkatan dampak buruk kegiatan manusia pada habitat organisme menyebabkan kehilangan nilai-nilai produksi, genetik, konservasi, dan membuat kepentingan restorasi ekosistem dalam skala luas juga meningkat (Hobbs \& Norton, 1996). Ekosistem terumbu karang di Teluk Saleh Nusa Tenggara Barat merupakan wilayah telah menjadi perhatian pemerintah dalam program rehabilitasi dan pengkayaan habitat. Terumbu karang di wilayah tersebut mengalami kerusakan berat akibat kegiatan penangkapan ikan dengan cara-cara yang merusak. Laporan masyarakat setempat menyebutkan bahwa kegiatan penangkapan ikan dengan bom sudah berlangsung lama dan meluas di beberapa pulau. Kegagalan pemerintah daerah dalam menanggulangi kerusakan terumbu karang tersebut disebabkan oleh kurangnya baseline data dan konsep pengelolaan sumber daya yang strategis di samping lemahnya kelembagaan dan penegakan hukum.

\footnotetext{
-) Peneliti pada Balai Riset Perikanan Laut, Jakarta

*) Peneliti pada Balai Pengkajian Teknologi Pertanian, Maluku
} 
Dalam kegiatan evaluasi dan monitoring, terutama sekali pada program rehabilitasi habitat, baseline data dibutuhkan mulai dari awal program sampai akhir program. Pada banyak kasus, program rehabilitasi bertujuan untuk mengembalikan sistem yang rusak sehingga mampu membentuk kondisi ekosistem karang yang bersifat protektif, produktif, dan estetik yang menyenangkan atau dapat bernilai dari sudut pandang konservasi atau kelestarian lingkungan dan sosial.

Identifikasi terjadinya perubahan dalam area perairan pantai yang direhabilitasi membutuhkan indikator. Penggunaan suatu jenis biota sebagai indikator adalah diukur dari kemampuannya dalam memperlihatkan tanda-tanda yang dapat diukur oleh pengamat pada waktu sedini mungkin. Karena, pemulihan terumbu karang yang rusak adalah suatu proses jangka panjang. Indikator pertama yang dapat digunakan untuk mengkaji perubahan-perubahan seiring waktu dalam tingkat populasi adalah komunitas ikan. Beberapa alasan pemilihan ikan sebagai indikator di antaranya adalah 1) Ikan merupakan satu kesatuan dari sistem kehidupan karang, tanggapan-tanggapannya cukup mencerminkan adanya proses-proses yang mengancam atau yang mendukung sistem tersebut secara keseluruhan, dan termasuk mempengaruhi berbagai komponen lainnya (Gomez \& Yap, 1984); 2) ikan adalah organisme yang relatif lebih kompleks, di mana banyak aspek biologi dan perilakunya dapat digunakan untuk mengukur tingkat kesesuaian habitatnya, seperti ikan kepe-kepe (Chaetodontidae), predator polyp karang; 3) Ikan karang memiliki hubungan yang erat sekali dengan karang dengan berbagai ketergantungan dan ini berguna untuk memantau pengaruhnya pada terumbu karang atau sebagai indikator yang sensitif untuk menentukan kondisi terumbu karang (Vivien \& Navarro, 1983; Reese, 1977, 1981). Perubahanperubahan dalam distribusi dan kelimpahan ikan karang dapat menjadi suatu petunjuk bahwa komunitas karang telah mengalami gangguan atau tekanan. Selain itu, ikan tersebut dapat berguna dalam mendeteksi beberapa keadaan pada tingkat yang rendah, dengan polusi yang kronis melampaui periode waktu yang panjang atau ikan dapat berguna dalam mendeteksi keadaan-keadaan tanpa gangguan seperti hanya sekadar untuk mengetahui struktur karang (Manthachitra et al., 1991).

Penelitian ini diharapkan memiliki 2 sisi kepentingan; pertama, untuk menyediakan data dasar bagi program rehabilitasi dan pengkayaan habitat perairan pantai yang akan direalisasikan oleh Departemen Kelautan dan Perikanan; dan kedua, untuk mengevaluasi kondisi struktur komunitas ikan karang pada area yang mengalami degradasi akibat kegiatan manusia.

Tujuan penelitian untuk mengindentifikasi keanekaragaman jenis, tingkat dominasi, keseimbangan populasi, dan kepadatan jenis ikan karang di Pulau
Rakiti dan Pulau Taikabo, Teluk Saleh Nusa Tenggara Barat. Data dan informasi ini diharapkan sebagai referensi bagi Pemerintah Daerah setempat dalam menentukan kebijakan pengelolaan perikanan di Teluk Saleh.

\section{BAHAN DAN METODE}

Kegiatan penelitian dilaksanakan pada bulan Agustus 2004 di wilayah perairan karang Pulau Rakiti dan Pulau Taikabo, Teluk Saleh, Nusa Tenggara Barat (Gambar 1). Kondisi umum lokasi penelitian di mana garis transek ditempatkan dapat dilihat pada Tabel 1 .

Survei ini dilakukan dengan pendekatan sensus visual pada garis transek (English et al., 1994). Data ikan karang didapat melalui penyelaman sepanjang garis transek $70 \mathrm{~m}$, dengan luas area sensus $(5 \times 100)$ $\mathrm{m}^{2}$. Jenis dan perkiraan jumlah ikan dicatat dalam data sheet kedap air. Identifikasi jenis ikan menggunakan buku petunjuk bergambar (Kuiter, 1992; Lieske \& Myers, 1997). Penyelaman pendahuluan dilakukan untuk membuat daftar spesies baku ikan setempat. Ikan karang dikelompokkan menurut statusnya, seperti ikan indikator, ikan major, dan ikan target (English et al., 1994). Ikan indikator kebanyakan dari suku Chaetodontidae yang kehadirannya dapat merefleksikan kondisi kesehatan karang. Ikan major adalah golongan ikan hias dan non ikan hias yang selalu berasosiasi dengan karang, baik sebagai penetap maupun pelintas. Ikan target adalah dari golongan ikan yang biasa dicari oleh nelayan untuk dimakan dan dijual.

Analisis keragaman hayati ikan karang menggunakan beberapa indeks yang dianggap penting sebagai baseline data. Indeks-indeks itu adalah indeks kekayaan jenis (richness indices), indeks keanekaragaman (diversity indices), dan indeks keseimbangan (evenness indices) (Ludwig \& Reynold, 1988).

Indeks kekayaan jenis (richness indices) mengacu pada:

1. Indeks Margalef $\left[R_{1}=(S-1) / \ln (n)\right]$

2. Indeks Menhinick $[R 2=S / \sqrt{ } n]$

di mana:

$\mathrm{S}$ = banyaknya jenis

$\mathrm{n}$ = jumlah individu ikan untuk semua jenis

Indeks Keanekaragaman mengacu pada:

1) Indeks Simpson $\left[\lambda=\sum\left\{\left(n_{i}\left(n_{i}-1\right) /(N(N-1)\}\right]\right.\right.$

2) Indeks Shanron $\left[H=\Sigma\left\{\left(n_{i} / N\right) \ln \left(n_{i} / N\right)\right\}\right]$

di mana:

$n_{i}=$ jumlah ikan jenis ke-i

$\mathrm{N}=$ total individu ikan untuk semua jenis 


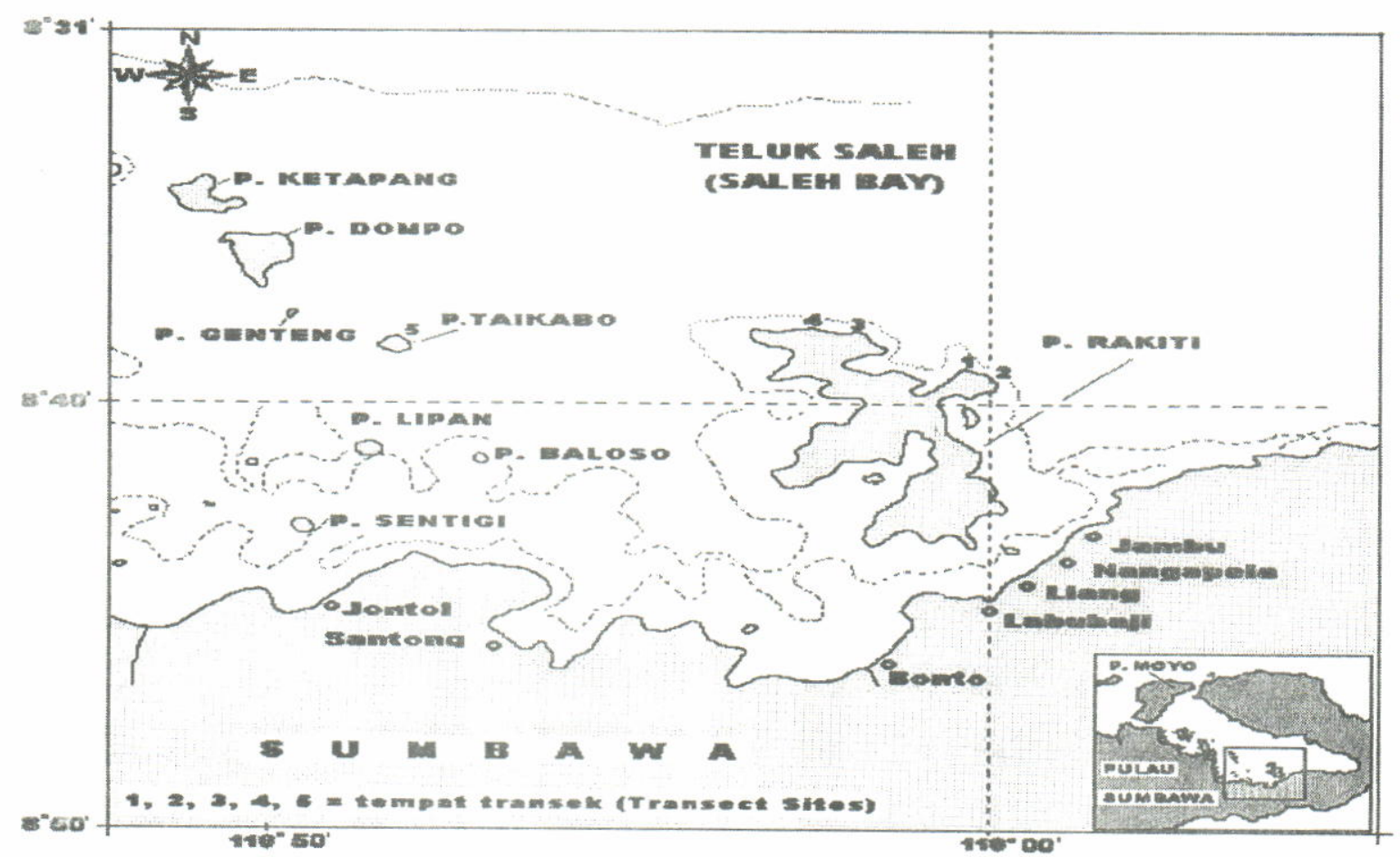

Gambar 1. Peta lokasi penelitian di Teluk Saleh, Sumbawa, Nusa Tenggara Barat. Figure 1. The Study site map of Saleh Bay, Sumbawa, Nusa Tenggara Barat.

Tabel 1. Gambaran umum lokasi transek pada setiap stasiun Table 1. General description of transect location by stations

\begin{tabular}{|c|c|c|c|c|c|}
\hline $\begin{array}{l}\text { Stasiun } \\
\text { (Station) }\end{array}$ & $\begin{array}{l}\text { Posisi Geografis } \\
\text { Transek } \\
\text { (Geographical } \\
\text { Position of the } \\
\text { Transects) }\end{array}$ & $\begin{array}{c}\text { Dasar Perairan dan } \\
\text { Persentasi Tutupan Karang } \\
\text { (Sea Bottom \& } \\
\text { Percent Cover of Corals }) \\
\end{array}$ & $\begin{array}{l}\text { Jarak Pandang } \\
\text { Horizontal } \\
\text { (Body Water } \\
\text { Visibility) }\end{array}$ & $\begin{array}{l}\text { Kedalaman } \\
\text { \& Arus Air } \\
\text { (Depth \& } \\
\text { Water } \\
\text { Current) }\end{array}$ & $\begin{array}{c}\text { Lokasi } \\
\text { (Study site) }\end{array}$ \\
\hline $\begin{array}{l}1 . \\
\text { Tj. Bila } \\
1\end{array}$ & $\begin{array}{c}08^{\circ} 37^{\prime} 36,7^{\prime \prime} \\
117^{\circ} 59^{\prime} 58,4^{\prime \prime}\end{array}$ & $\begin{array}{l}\text { Pasir }(10 \%) \\
\text { Rubble (80\%) } \\
\text { Karang hidup (5\%) }\end{array}$ & $\begin{array}{l}\text { Buruk } \\
(5 \mathrm{~m})\end{array}$ & $\begin{array}{l}7 \text { meter; } \\
\text { sedang }\end{array}$ & $\begin{array}{l}\text { Pulau Rakiti, } \\
\text { tanpa penduduk, } \\
\text { area rusak berat }\end{array}$ \\
\hline $\begin{array}{l}2 . \\
\text { Tj. Bila } \\
2\end{array}$ & $\begin{array}{l}08^{\circ} 37^{\prime} 40,0^{\prime \prime} \\
118^{\circ} 00^{\prime} 14,8^{\prime \prime}\end{array}$ & $\begin{array}{l}\text { Pasir putih }(70 \%) \\
\text { Rubble \& karang mati }(20 \%), \\
\text { Karang hidup (5\%) }\end{array}$ & $\begin{array}{l}\text { Baik } \\
(10 \mathrm{~m})\end{array}$ & $\begin{array}{l}\text { 3-5 meter; } \\
\text { lemah }\end{array}$ & $\begin{array}{l}\text { Pulau Rakiti, } \\
\text { area berpasir, } \\
\text { kondisi karang rusak }\end{array}$ \\
\hline$\underset{\text { Pateri }}{3 .}$ & $\begin{array}{c}08^{\circ} 38^{\prime} 47,0^{\prime \prime} \\
117^{\circ} 57^{\prime} 54,0^{\prime \prime}\end{array}$ & $\begin{array}{l}\text { Reef plate, } \\
\text { Pasir }(20 \%) \text {, rubble }(30 \%) \\
\text { Karang mati }(20 \%) \text {, } \\
\text { Karang hidup }(25 \%)\end{array}$ & $\begin{array}{l}\text { Baik } \\
(10 \mathrm{~m})\end{array}$ & $\begin{array}{l}\text { 2-4 meter; } \\
\text { lemah }\end{array}$ & $\begin{array}{l}\text { Pulau Rakiti, } \\
\text { area karang rusak, } \\
\text { karang rusak berat } \\
\text { pada kedalaman di } \\
\text { atas } 4 \mathrm{~m}\end{array}$ \\
\hline $\begin{array}{l}4 . \\
\text { Tj. } \\
\text { Padang }\end{array}$ & $\begin{array}{c}08^{\circ} 36^{\prime} 43,8^{\prime \prime} \\
117^{\circ} 57^{\prime} 06,3^{\prime \prime}\end{array}$ & $\begin{array}{l}\text { Reef plate, } \\
\text { pasir \& batuan }(5 \%), \\
\text { rubble \& karang mati }(10 \%), \\
\text { Karang lunak }(50 \%) \\
\text { Karang hidup }(30 \%)\end{array}$ & $\begin{array}{l}\text { Baik } \\
(10 \mathrm{~m})\end{array}$ & $\begin{array}{l}5 \text { meter; } \\
\text { lemah }\end{array}$ & $\begin{array}{l}\text { Pulau Rakiti, } \\
\text { area terumbu yang } \\
\text { relatif baik, kaya } \\
\text { akan karang lunak, } \\
\text { area berbatasan } \\
\text { dengan reef slope } \\
\text { (area tubir). }\end{array}$ \\
\hline $\begin{array}{c}5 . \\
\text { P. } \\
\text { Taikabo }\end{array}$ & $\begin{array}{l}08^{\circ} 39^{\prime} 20,9^{\prime \prime} \\
117^{\circ} 51^{\prime} 29,0^{\prime \prime}\end{array}$ & $\begin{array}{l}\text { Reef slope, pasir }(25 \%) \\
\text { rubble \& karang rusak (30\%) } \\
\text { Karang lunak }(20 \%) \\
\text { Karang hidup }(20 \%)\end{array}$ & $\begin{array}{l}\text { Sedang } \\
(7 \mathrm{~m})\end{array}$ & $\begin{array}{l}\text { 6-7 meter; } \\
\text { sedang }\end{array}$ & $\begin{array}{l}\text { Pulau Taikabo, } \\
\text { tanpa penduduk, } \\
\text { area karang rusak, } \\
\text { area berbatasan } \\
\text { dengan reef plate. }\end{array}$ \\
\hline
\end{tabular}


Karena dominasi suatu populasi dalam komunitas juga mempengaruhi keseimbangan ekosistem, berarti besaran nilai indeks keanekaragaman $(\mathrm{H})$ bukan hanya tergantung pada nilai Indeks Simpson atau indeks dominasi, tetapi juga sangat ditentukan oleh nilai indeks keseimbangan populasi dalam suatu komunitas. karena itu analisis data ini juga memperhitungkan indeks-indeks keseimbangan. Pada beberapa tulisan indeks ini juga disebut indeks kemerataan. Indeks tersebut antara lain adalah:

$$
\begin{aligned}
& \text { Indeks Pielou }\left[E_{1}=\{H / \ln (S)\}\right] \\
& \text { Sheldon }\left[E_{2}=\left(e^{H} / S\right)\right] \\
& \text { Heip }\left[E_{3}=\left\{\left(e^{H}-1 /(S-1)\right\}\right]\right. \\
& \text { Hill }\left[E_{4}=\left\{(1 / \lambda) / e^{H}\right\}\right] \\
& \text { Modifikasi dari Hill }\left[E_{5}=\{(1 / \lambda)-1\} /\left(e^{H}-1\right)\right]
\end{aligned}
$$

di mana:

$$
\begin{aligned}
& S=\text { banyaknya jenis } \\
& H=\text { Indeks Shannon } \\
& \lambda=\text { Indeks Simpson } \\
& e=\text { bilangan natural }
\end{aligned}
$$

Analisis hasil penelitian lebih terfokus pada Indeks Shannon $(H)$, Indeks Simpson $(\lambda)$ atau indeks dominasi (D), dan indeks keseimbangan ( $E 1$; Pielou).

Indeks Simpson adalah identik dengan indeks dominasi $[D=(1-H)]$, di mana nilai kedua Indeks ini berbanding terbalik dengan Indeks Shannon. Semakin besar prediksi nilai dominasi terhadap komunitas biota, berarti semakin kecil nilai prediksi terhadap keanekaragaman komunitas tersebut. Dalam hal ini keanekaragaman komunitas dianggap terbaik jika nilai $\lambda$ atau $\mathrm{D}$ mendekati 0 dan terburuk jika nilainya mendekati 1 (misalnya terjadi pada lingkungan hidup yang mengalami tekanan atau pencemaran). Berarti bahwa kisaran nilai kedua indeks $(\lambda$ dan $D)$ tersebut antara 0 dan 1 . Semakin mendekati nilai 0 , menyebabkan nilai indeks $\mathrm{H}$ akan semakin besar (keanekaragaman hayati dianggap tinggi). Sebaliknya semakin mendekati 1 , menyebabkan nilai indeks $H$ semakin kecil (keanekaragaman hayati dianggap buruk). Dalam kondisi alamiah besarnya nilai Indeks $\mathrm{H}$ untuk komunitas ikan karang berkisar di antara nilai 3 (sedang). Dalam ekosistem yang matang seringkali nilai $\mathrm{H}$ menjadi $>3$. Dalam kondisi lingkungan yang buruk menyebabkan hanya sebagian kecil populasi biota yang bertahan dan menjadi berkembang mendominasi komunitas biota setempat. Ini berarti nilai indeks dominasi atau nilai Indeks Simpson untuk komunitas tersebut akan membesar dari 0 mendekati 1 dan akibatnya keanekaragaman $(\mathrm{H})$ mengecil dari 3 mendekati 1. Selain itu, unsur yang membentuk keanekaragaman hayati juga ditinjau dari banyaknya populasi yang menonjol (melimpah atau paling melimpah). Keragaman populasi ini mengacu pada besarnya diversity number dari Hill yaitu $\mathrm{N}_{1}$ dan $\mathrm{N}_{2}$, di mana $N_{1}$ ditafsirkan sebagai banyak populasi dari suatu spesies yang cukup melimpah, sedangkan $\mathrm{N}_{2}$ adalah banyaknya populasi dari suatu spesies yang paling melimpah. Rumusnya adalah:

$$
N_{1}=e^{H} \text { dan } N_{2}=1 / \lambda
$$

di mana:

$$
\begin{aligned}
& H=\text { Indeks Shannon } \\
& \lambda=\text { Indeks Simpson }
\end{aligned}
$$

Sementara sisanya digunakan sebatas bench mark bagi hasil kajian yang serupa. Sedangkan kepadatan ikan karang merupakan perhitungan jumlah individu per satuan luas transek ( $5 \mathrm{~m} \times 100 \mathrm{~m}$ ). Semua prosedural untuk perhitungan di atas menggunakan program Microsoft Excel.

\section{HASIL DAN BAHASAN}

Hasil sensus dan identifikasi ikan pada setiap lokasi disajikan pada Lampiran 1, sedangkan hasil analisis data ikan disajikan pada Tabel 2. Secara keseluruhan total jenis ikan yang teridentifikasi selama sensus adalah 105 spesies, tetapi jumlah jenis menurut lokasi bervariasi antara 34 sampai 57 spesies. Tingkat kepadatan individu berkisar antara 3,4 sampai 17,7 ekor per $\mathrm{m}^{2}$.

Hasil analisis menunjukkan bahwa jumlah suku, marga, dan jenis pada semua stasiun penelitian tergolong rendah jika dibanding pada area terumbu karang yang sehat. Kerusakan terumbu karang pulau Rakiti pada stasiun 1, 2, dan 3 tergolong parah seperti ditunjukkan oleh rendahnya jumlah jenis, tingkat kepadatan, dan indeks kekayaan jenis (Tabel 2). Sebagian besar jenis ikan yang biasa berassosiasi dengan terumbu karang tidak hadir di lokasi tersebut seiring dengan hilangnya habitat. Sebagaimana juga ditunjukkan oleh kecilnya jumlah suku yang hadir. Pada area yang didominasi oleh serpihan patahan karang mati seperti di stasiun 1 dan 3 dan/atau hamparan pasir di stasiun 2 (Tabel 1), umumnya banyak suku ikan karang yang tidak hadir. Seharusnya seperti yang tersedia dalam setiap habitat terumbu karang, ikan memiliki banyak relung ekologi yang spesifik yang mampu menampung ikan dengan keberagaman yang tinggi (Lieske \& Myers, 1997). Contohnya pada perairan Kepulauan Banda Maluku yang memiliki terumbu karang yang sehat, pada setiap lokasi transek dijumpai mulai dari 142 sampai 224 jenis ikan karang, di mana jenis-jenis ini berasal dari 33 sampai 41 suku (Edrus et al., 1992). Hasil ekspedisi Pulau Moyo tahun 1993, di mana pulau tersebut terletak di bagian utara Teluk Saleh, menunjukkan bahwa keanekaragaman ikan karang yang ditemukan masih cukup tinggi, yaitu meliputi 196 jenis yang berasal dari 76 marga dan 28 suku (Anonimous, 1993). Pada kasus kerusakan terumbu di Pulau Rakiti dan Taikabo saat ini, punahnya relung ekologi menyebabkan ikan kehilangan tempat tinggal yang sesuai dengan fungsi simbion, otoritas area, reproduksi, jaring makanan, dan fungsi ekologis lainnya dari masing-masing ikan karang. Hal ini, berakibat pada penurunan keanekaragam ikan karang di lokasi tersebut. 
Tabel 2. Kondisi ikan karang di pulau Rakiti dan Taikabo, Teluk Saleh, Sumbawa, Nusa Tenggara Barat, menurut stasiun penelitian

Table 2. The state of coral fish in the Islands of Rakiti and Taikabo, Saleh Bay, Sumbawa NTB, by study sites

\begin{tabular}{|c|c|c|c|c|c|c|}
\hline \multirow{2}{*}{ No. } & \multirow{2}{*}{$\begin{array}{l}\text { Katagori } \\
\text { (Catagories) }\end{array}$} & \multicolumn{5}{|c|}{$\begin{array}{l}\text { LOKASI } \\
\text { (Locations) }\end{array}$} \\
\hline & & St. 1 & St. 2 & St. 4 & St. 5 & St. 5 \\
\hline & $\begin{array}{l}\text { Kondisi taksonomi ikan: } \\
\text { (Description of fish taxonomy) }\end{array}$ & & & & & \\
\hline 1.1. & Jumlah jenis (Species number) & 36 & 34 & 56 & 57 & 55 \\
\hline 1.2. & Jumlah marga (Genus number) & 27 & 23 & 33 & 40 & 34 \\
\hline 1.3. & Jumlah suku (Family number) & 14 & 9 & 15 & 19 & 17 \\
\hline 2. & $\begin{array}{l}\text { Kondisi populasi ikan: } \\
\text { (Fish population state) }\end{array}$ & & & & & \\
\hline 2.1. & Richness Index, Margalef: R1 & 4,70 & 3,86 & 6,49 & 6,16 & 6,05 \\
\hline 2.2. & Menhinick Index: R2 & 0,87 & 0,52 & 0,81 & 0,61 & 0,63 \\
\hline 2.3 . & Simpson Diversity Index: Lambda & 0,14 & 0,12 & 0,09 & 0,09 & 0,08 \\
\hline 2.4 & St annon Diversity Index: H & 2,59 & 2,54 & 2,88 & 2,88 & 3 \\
\hline 2.5. & Hill's diversity Number: N1 & 13,29 & 12,70 & 17,86 & 17,79 & 20,11 \\
\hline 2.6. & Hill's diversity Number: N2 & 7,24 & 8,44 & 10,73 & 11,17 & 13,01 \\
\hline 2.7. & Evenness Index: E1 & 0,72 & 0,73 & 0,72 & 0,71 & 0,75 \\
\hline 2.8 & Evenness Index: E2 & 0,37 & 0,38 & 0,32 & 0,31 & 0,37 \\
\hline 2.9. & Evenness Index: E3 & 0,34 & 0,35 & 0,30 & 0,29 & 0,35 \\
\hline 2.10 . & Evenness Index: E4 & 0,54 & 0,66 & 0,60 & 0,63 & 0,65 \\
\hline 2.11 . & Evenness Index: E5 & 0,51 & 0,64 & 0,58 & 0,61 & 0,63 \\
\hline 2.12 . & Jumlah Individu (Individual number) & 1.711 & 3.965 & 4.775 & 8.856 & 7.555 \\
\hline 2.13 . & Kepadatan /density (individual per $\mathrm{m}^{2}$ ) & 3,4 & 7,9 & 9,5 & 17,7 & 15,11 \\
\hline 3. & $\begin{array}{l}\text { Pengelompokan ikan: } \\
\text { (Fish groups) }\end{array}$ & & & & & \\
\hline 3.1. & Percentage of the major fishes $(\mathrm{M} ; \%)$ & 77,8 & 61,8 & 58,9 & 66,7 & 72,7 \\
\hline 3.2. & Percentage of the target fishes $(T ; \%)$ & 19,4 & 29,4 & 33,9 & 29,8 & 25,5 \\
\hline 3.3. & Percentage of indicator fishes $(1 ; \%)$ & 2,8 & 8,8 & 7,1 & 3,5 & 1,8 \\
\hline
\end{tabular}

Rusaknya habitat ikan di terumbu karang juga ditunjukkan oleh rendahnya berbagai indeks ekologi (Tabel 2). Indeks keanekaragaman $(\mathrm{H})$ ikan karang umumnya lebih kecil dari 3. Pada kondisi terumbu karang yang sehat biasanya indeks $\mathrm{H}$ lebih besar dari 3. Selain itu, sebagaimana yang ditunjukkan oleh Hill's diversitry Number (indeks N1 dan N2), keragaman populasi ikan karang yang biasanya berkoloni dengan jumlah individu tinggi relatif sedikit dijumpai pada stasiun 1 dan 2 . Sebaliknya pada stasiun 3,4 , dan 5 keragaman pupolasi tersebut dijumpai lebih banyak. Contoh dari populasi ini umumnya adalah ikan-ikan yang termasuk suku Apogonidae, Labridae, dan Pomacentridae (Lampiran 1). Perkembangan koloni tersebut diprediksi masih dalam tingkat normal. Hal ini, ditunjukkan oleh indeks dominasi (D; Indeks Simpson) dan Indeks Keseimbangan Populasi (Evenness). Indeks-indeks tersebut (Tabel 2) menunjukkan bahwa pada setiap lokasi penelitian, meskipun mengalami degradasi habitat tetapi badan air tidak mengalami gangguan, sehingga tidak ada kondisi ekstrim yang mendukung dominasi dari satu atau lebih pupulasi ikan. Seperti diketahui bahwa pertumbuhan koloni yang sangat pesat pada kondisi yang ekstrim (polusi) terjadi karena kondisi yang spesifik dan menguntungkan (favorable), khususnya bagi populasi yang mampu berkembang tersebut (Odum, 1971). Dalam kasus ini, kelangkaan habitat yang termasuk relung ekologi adalah faktor pembatas untuk perkembangan semua koloni dari populasi ikan karang. Oleh karenanya, tidak ada dominasi yang terjadi secara signifikan. Kondisi demikian membawa kepada keseimbangan populasi yang stabil pada setiap lokasi penelitian.

Kelompok ikan mayor (kelompok ikan karang sejati atau ikan hias) masih dijumpai sebagai kelompok terbanyak di area terumbu karang Pulau Rakiti dan Pulau Taikebo (antara 59 sampai $78 \%$ ). Potensi dari kelompok ikan target atau ikan pangan berkisar antara 19 sampai $30 \%$ (Tabel 2). Sedangkan kelompok ikan indikator, sebagian besar ikan kepe-kepe yang merupakan petunjuk kesehatan terumbu karang dan memiliki nilai ekonomis tinggi, dijumpai dalam proporsi yang sangat rendah (antara 2 sampai 9\%). Kelompok 
ikan mayor tergolong banyak pada stasiun 1 dan 5 . Sedangkan pada stasiun 2, 3, dan 4 tergolong sedang. Kelompok ikan pangan tergolong banyak pada stasiun 3 dan 4 , tergolong sedang pada stasiun 5 dan sedikit pada stasiun 1 dan 2. Sedangkan kelompok ikan indikator tergolong sedikit pada semua lokasi, di mana hal ini merupakan pertanda dari rendahnya keanekaragaman terumbu karang keras (Hard corals) yang hidup di lokasi-lokasi tersebut (Nash, 1989). Sebagian kecil jenis-jenis ikan yang termasuk kelompok mayor masih mampu bertahan pada area penelitian dari habitat yang masih tersedia. Seperti misalnya kelompok pomacentridae, labridae, apogonidae, blennidae, dan gobidae masih memiliki area teritorial dan simbionnya masing-masing. Jenisjenis yang termasuk kelompok mayor hidup berasosiasi dengan karang hidup (seperti jenis ikan Pomacentridae, Labridae, dan Balistidae) dan juga ada yang hidup dicelah karang hidup dan batuan karang mati (Apoginidae dan Muraenidae) dan hidup di dalam batuan dan pasir (Pinguipedidae, Sinodontidae, Blenidae, dan Gobidae). Sedangkan kelompok ikan target, yang juga dalam jumlah kecil, masih ditemukan di lokasi penelitian menurut fungsinya masing-masing, seperti misalnya sebagai predator (seperti jenis-jenis Serranidae, Carangidae, dan Haemulidae), sebagai pemakan rumput laut dan ganggang (Acanthuridae, Lutjanidae, Mullidae, Nemipteridae, Scaridae, dan Siganidae) dan sebagai predator serta pelintas area terumbu karang (Caesionidae dan Carangidae). Kelompok ketiga, ikan indikator, hadir dalam jumlah yang sangat kecil sekali, yaitu antara 1 sampai 4 jenis menurut lokasi transek. Ikan indikator (Chaetodontidae) sebagian besar merupakan omnivora, tetapi makanan kegemarannya adalah polyp karang. Hilangnya berbagai jenis karang menyebabkan ketidakhadiran banyak jenis Chaetodontidae di suatu perairan karang, seperti juga ketidakhadiran berbagai jenis ikan pemakan polyp lainnya dari golongan suku Balistidae, Scaridae, dan Tetraodontidae (White, 1987). Pada kondisi buruk, jenis Chaetodontidae yang biasa bertahan hidup di area pecahan karang dan air yang agak keruh adalah Chaetodon klenii dan Parachaetodon ocellatus. Besarnya jumlah jenis $P$. ocellatus di suatu perairan, sementara jenis dari Chaetodontidae yang lain menghilang, merupakan pertanda buruk kerusakan terumbu karang di wilayah perairan Teluk Saleh.

Ikan karang membutuhkan habitat hidup untuk bersarang dan mencari makan. Umumnya ikan karang memiliki mobilitas yang rendah, oleh karenanya sarang sebagai tempat bertahan hidup dan berlindung sangat penting untuk keberlanjutan fungsinya di dalam area otoritas yang telah dipertahankannya. Semua kebutuhan ikan karang telah disediakan oleh terumbu karang sebagai suatu ekosistem yang secara co-evolution telah berkembang bersama-sama dengan ikan karang. Asssosiasi ikan karang dengan terumbu karang sangat erat, sehingga eksistensi ikan karang di suatu wilayah terumbu karang sangat rapuh ketika terjadi pengrusakan habitatnya. Dengan sifatnya ini pula maka ikan karang dapat dijadikan indikator yang baik untuk mengetahui tingkat kerusakan habitat. Kerusakan terumbu karang di Pulau Rakiti dan Taikabo perairan Teluk Saleh merupakan contoh baik, yang menunjukkan kehilangan biodiversitas ikan karang, baik jenisnya maupun relung ekologisnya. Berbagai fungsi ekologis ikan karang di perairan tersebut tidak terpenuhi karena hilangnya pelindung (shelter), area otoritas, organisme simbion, rantai makanan, tempat memijah, dan tempat mengasuh. Oleh karenanya, tingkat keanekaragaman ikan karang menjadi rendah.

Peningkatan daya dukung lingkungan melalui gerakan rehabilitasi diharapkan mampu mengembalikan keanekaragaman ikan karang di wilayah tersebut. Area penelitian yang termasuk stasiun 1 sampai dengan 5 merupakan area yang mengalami kerusakan berdasarkan jumlah kehadiran jenis ikan karang. Dari segi fisik substrat dasar perairan (Tabel 1) stasiun 1 , 2 , dan 3 cocok untuk calon area yang akan direstorasi (habitat enhancement), sedangkan stasiun 4 dan 5 cocok untuk area konservasi atau area yang dilindungi (protected area). Penempatan terumbu buatan di stasiun 1, 2, dan 3 diharapkan akan mampu meningkatkan proporsi dan jumlah ikan pangan di wilayah tersebut. Pada tahap selanjutnya dalam periode suksesi ekologis, jumlah ikan karang yang semula berjumlah 34 sampai 57 jenis sebelum penempatan terumbu buatan, setelah 1 dekade pasca penempatan terumbu diasumsikan dapat meningkat melebihi 100 jenis pada setiap lokasi terumbu buatan (Edrus, 2002). Asumsi ini cukup beralasan karena total ikan karang yang ditemukan sekarang pada seluruh lokasi sedikitnya 105 jenis dan terumbu buatan memiliki daya afinitas (atraktan) yang kuat untuk menarik kedatangan ikan-ikan karang dan ikan-ikan pelagis.

\section{KESIMPULAN DAN SARAN}

\section{Kesimpulan}

1. Total jenis ikan yang teridentifikasi adalah 105 spesies. Jumlah jenis menurut lokasi bervariasi antara 34 sampai 57 spesies. Kepadatan individu per meter persegi berkisar antara 3,4 sampai dengan 17,7 ekor.

2. Semua lokasi penelitian, kecuali Tanjung Padang (stasiun 4), merupakan lokasi perairan karang yang mengalami kerusakan habitat.

3. Indeks keanekaragaman ikan karang di semua lokasi tergolong dalam kategori rendah, bervariasi antara 2,54 sampai dengan 3 . 
4. Kondisi komunitas ikan karang cukup baik, artinya tidak ada dominasi populasi dan keseimbangan antar populasi tergolong stabil.

5. Proporsi antara ikan mayor, ikan target, dan indikator adalah normal, masing-masing rata-rata $68 \%, 28 \%$, dan $5 \%$.

\section{Saran}

1. Pulau Taikabo layak untuk dikonservasi dengan pemanfaatan yang terbatas.

2. Tanjung Padang (stasiun 4) layak untuk dilindungi sebagai sumber plasma nutfah (protected area) dan sekitarnya harus dilindungi dari kegiatan penangkapan yang merusak.

3. Rencana penempatan terumbu karang buatan (artificial reefs) dapat diimplementasikan pada stasiun 1, 2, dan 3 .

4. Semua data yang berupa indeks ekologi yang merupakan hasil penelitian ini dapat digunakan sebagai baseline data (gambaran rona awal lingkungan) bagi penelitian-penelitian dampak rehabilitasi (habitat enhancement) dikemudian hari, jika proyek tersebut akan diimplementasikan pada lokasi yang sama.

\section{DAFTAR PUSTAKA}

Anonimous. 1993. Laporan ekspedisi Pulau Moyo, 17 September-7 Oktober 1993. Lembaga IImu Pengetahuan Indonesia, Jakarta.

Edrus, I. N., A. R. Syam, \& La Sui. 1992. Potensi, pemanfaatan dan prospek pengembangan perikanan karang di Kepulauan Banda, Maluku Tengah, dalam hubungannya dengan kepariwisataan. Jurnal Penelitian Perikanan Laut 74: 32-39.

Edrus, I. N. 2002. Assessment of community participation in the coastal resource rehabilitation project in Bali, Indonesia. Thesis. University of The Phillippines Los Banos.

English, S., C. Wilkinson, \& V. Baker. 1994. Survey manual for tropical marine resources. Australian Institute of Marine Science, Townsville. Australia.

Hobbs, R. J. \& D. A. Norton. 1996. "Commentary: towards a conceptual framework for restoration Ecology". Restoration Ecology 4 (2): 93-110.

Gomez, E. D. \& H. T. Yap. 1984. Monitoring reef condition. In: coral reef management handbook. R. A. Kenchingt6on \& B. E. T. Hudson (Eds). Unesco Publisher, Jakarta, 1984.
KPP-COREMAP. 2001. Buku panduan pengelolaan berbasis masyarakat (PBM)-COREMAP. COREMAPLembaga IImu Pengetahuan Indonesia, Jakarta.

Kuiter, R. H. 1992. Tropical reef-fishes of the Western Pacific Indonesia and adjacent waters. Gramedia, Jakarta.

Lieske, E. \& R. Myers. 1997. Reef fishes of the world. Periplus Edition. Jakarta, Indonesia.

Ludwig, J. A. \& J. F. Reynolds. 1988. Statistical ecology. A primer on methods and computing. Jhon Wiley \& Son, New York. 337 p.

Manthachitra, V., S. Sudara, \& S. Satumanapatpan. 1991. Chaetodon octofasciatus as indicator species for reef condition. In: proceeding of the regional symposium on living resources in coastal water areas, A. C. Alcala (Ed), 30 January-1 February 1989, Marine Science Institute, University of the Philippines, Manila, Philippines.

Nash, S. V. 1989. Reef diversity index survey method for non sspecialist. Tropical Coastal Area Management Vol.4 (3): 14-17.

Odum, E. P. 1971. Fundamental of ecology. $3^{\text {rd }}$ ed. W. B. Sounder co., Philadelphia, p.131.

Reese, E. 1977. Coevolution of coral and coral feeding fishes of family Chaetodontidae. Proceeding of the third International Coral Reef Symposium 1: 267-274.

Reese, E. 1981. Predation on corals by fishes of the family Chaetodontidae: implication for conservation and management of coral reef ecosystem. Bulletin of Marine Science 31 (3): 594-604.

Nontji, A. 2002. Coral reefs of Indonesia: Past, present, and future. Prosiding Loka Karya Pengelolaan dan IImu Pengetahuan Terumbu Karang Indonesia. Program Rehabilitasi dan Pengelolaan Terumbu Karang. Lembaga IImu Pengetahuan Indonesia.

Vivien, H. M. L. \& Y. B. Navarro. 1983. Feeding diets and significance of coral feeding among chaetodontid fishes in Moorea (French Polynesia). Coral Reefs 2:119-127.

White, A. T. 1987. Coral Reefs: Valuable Resources of Southeast Asia. ICLARM Education Series 1, Manila, Philippines, No.386. 36 p.

Wilkinson, C. R. \& R. W. Buddemeier. 1994. Global climate change and coral reefs: implications for people and reefs. Report of the UNEP-IOCASPEI-IUCN Global Task Team on the Implication of Climate Change on Coral Reefs. IUCN Publications Service Unit, Cambridge. 


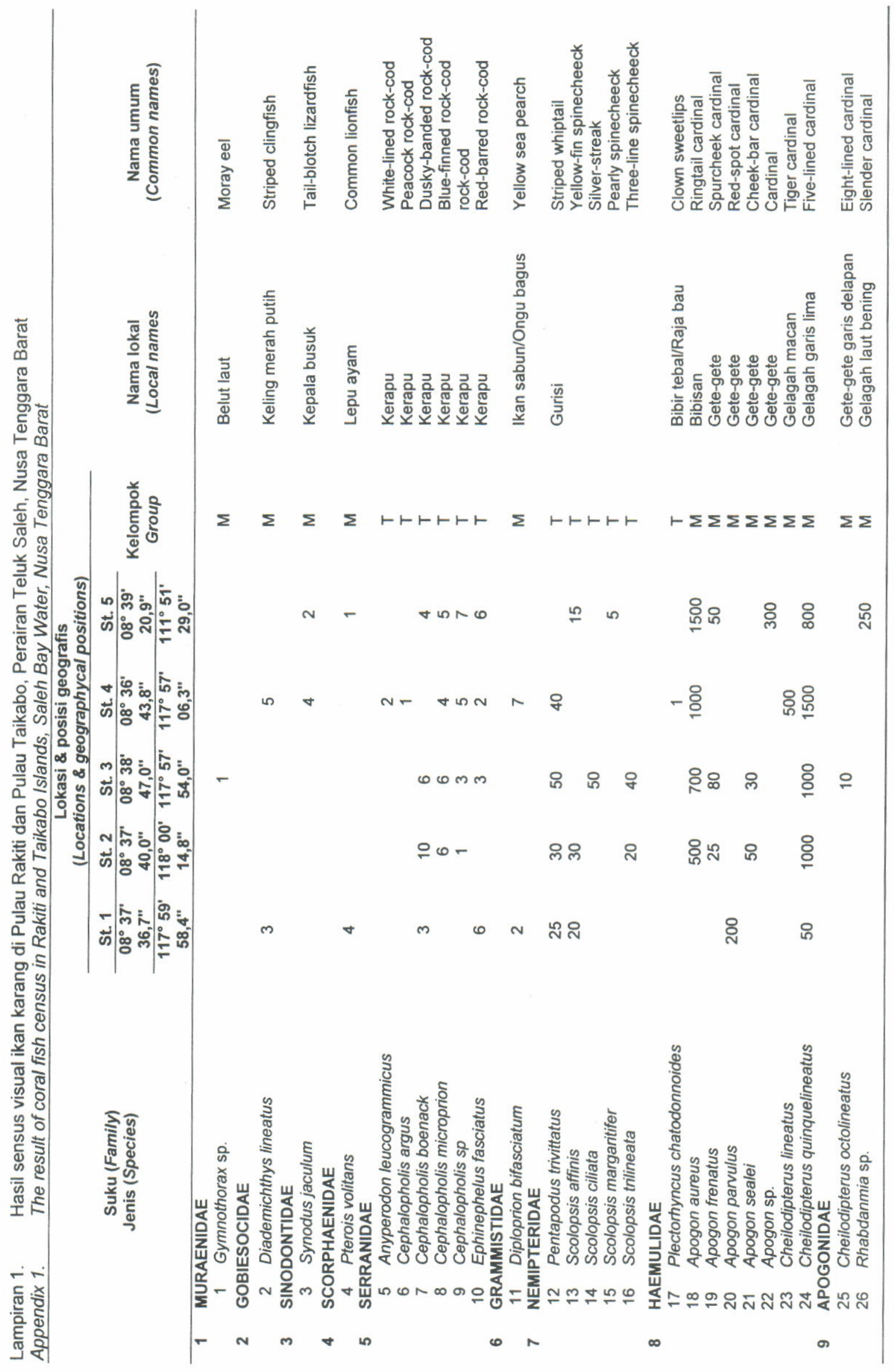




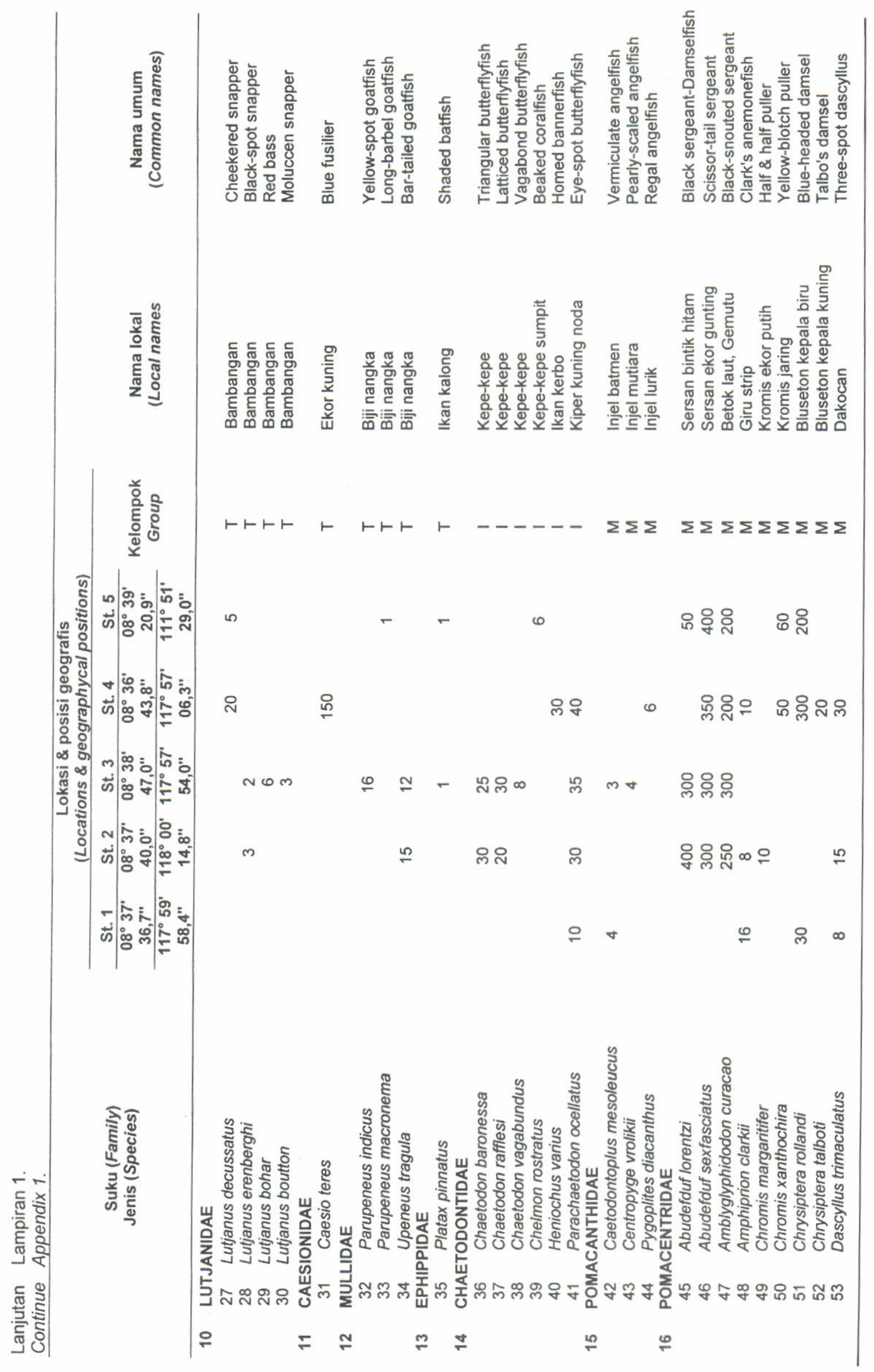




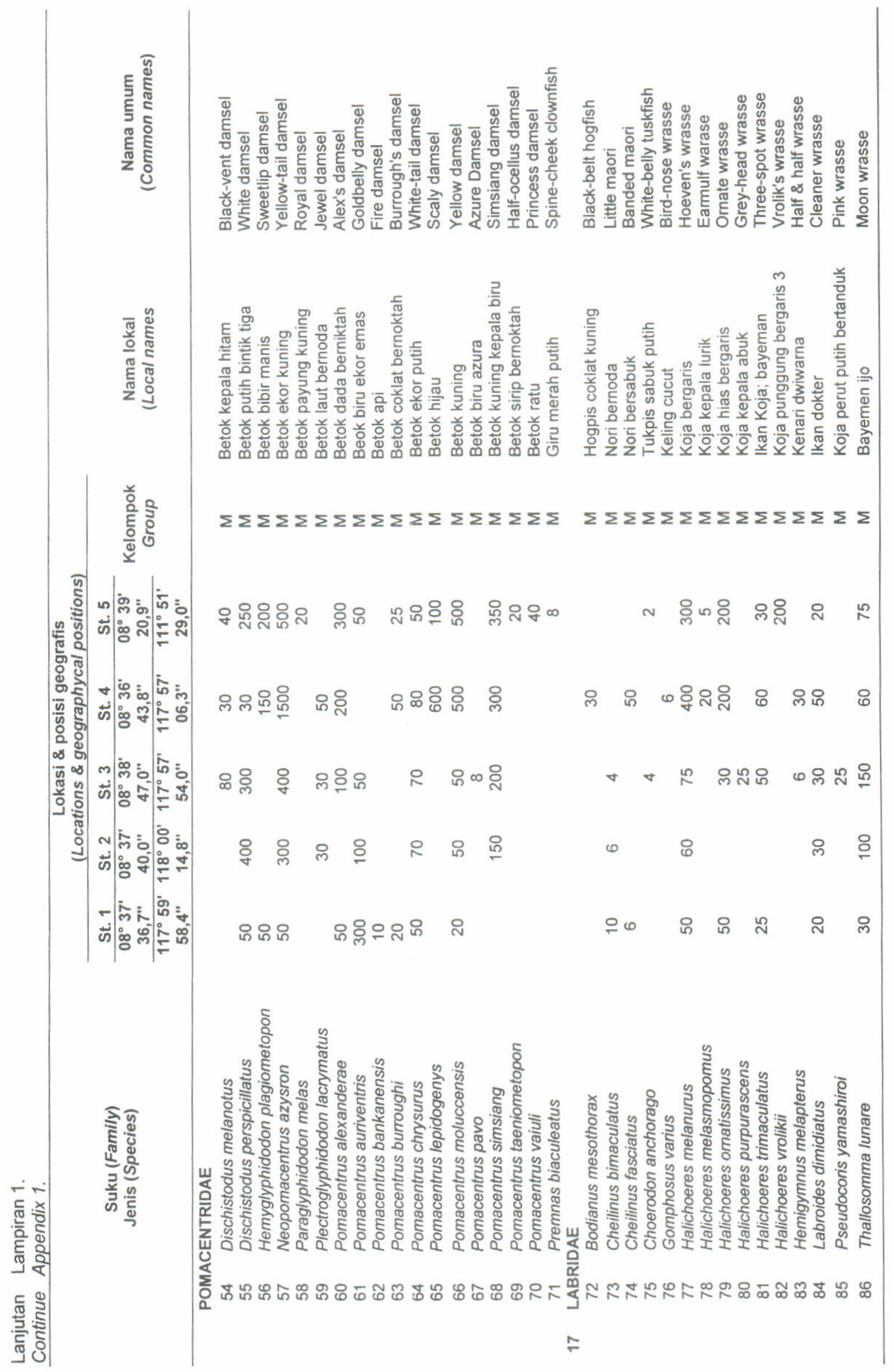




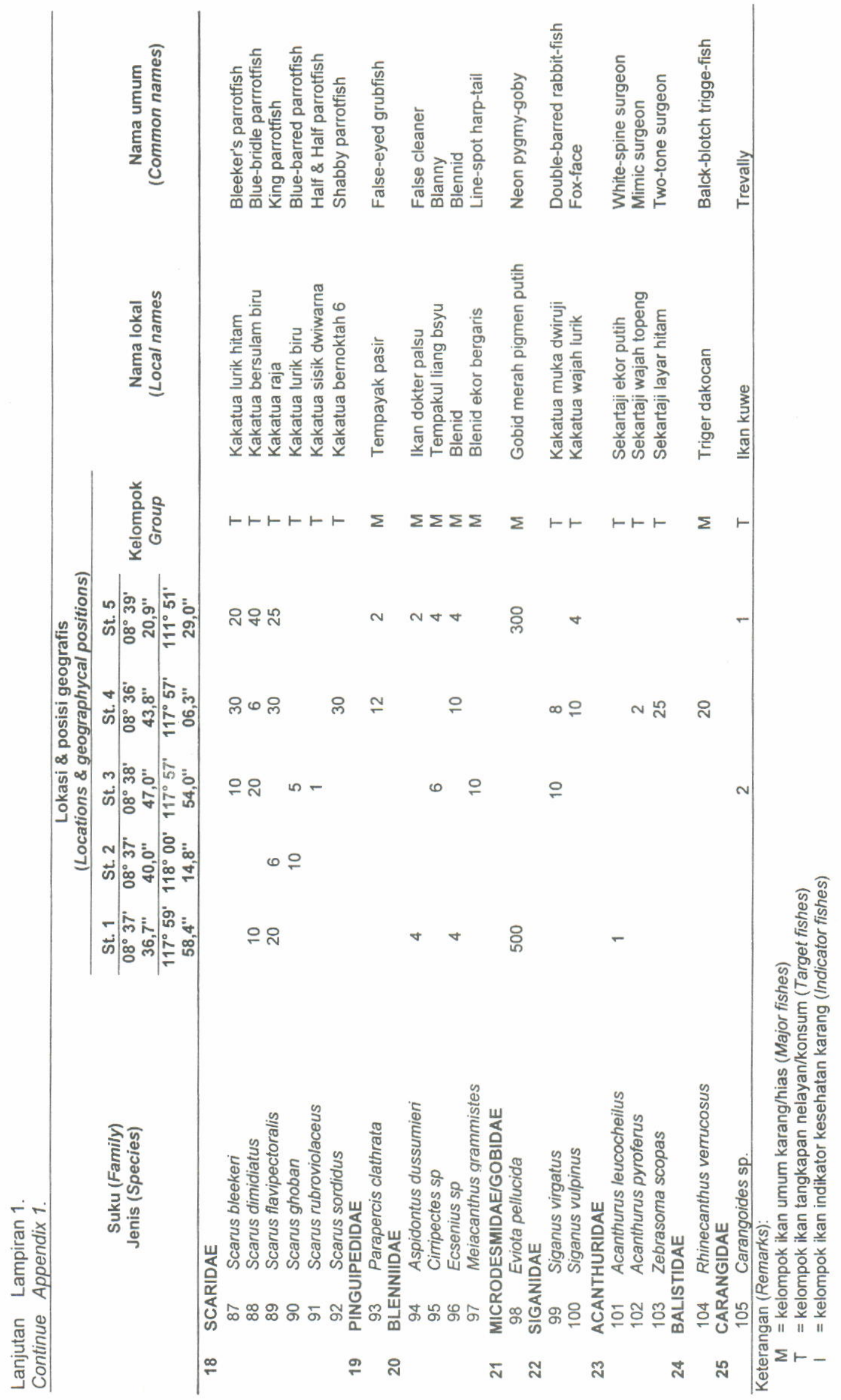


